\title{
ANALISIS PENDAPATAN PETERNAKAN AYAM BROILER POLA KEMITRAAN DI KECAMATAN NANGGUNG KABUPATEN BOGOR
}

\author{
NM. Akbar Illahi ${ }^{1 \mathrm{a}}$, I. Novita ${ }^{1}$ dan S. Masitoh ${ }^{1}$ \\ ${ }^{1}$ Jurusan Agribisnis, Fakultas Pertanian Universitas Djuanda Bogor \\ Jalan Tol Ciawi No. 1 Kotak Pos 35 Bogor 16720 \\ aKKorespondensi: Nur M Akbar Illahi, Email : aqbarkurniawan@gmail.com
}

\begin{abstract}
ABSTRAK
Dalam mengembangkan usaha ternak ayam broiler peternak melakukan usaha dengan menjalin pola kemitraan, sehingga peternak dibantu oleh perusahaan dalam menyediakan sapronak dan pemasaran. Penelitian ini bertujuan untuk mengetahui pola kemitraan antara peternak dan perusahaan, biaya, penerimaan, pendapatan, keuntungan, R/C dan Break Event Point (BEP) pada usaha ternak ayam broiler. Penelitian ini dilakukan pada bulan Februari hingga Maret 2019 di Kecamatan Nanggung. Metode penelitian sampel menggunakan metode sesus dengan jumlah sampel 18 peternak mitra. Pengolahan dilakukan secara deskriptif dan kuantitatif (analisis pendapatan, analisis R/C ratio dan Break Event Point). Secara umum penelitian ini menunjukkan hubungan yang dilakukan antara peternak ayam broiler dan perusahaan yaitu pola Inti-Plasma dan kerjasama operasional agribisnis (KOA). Hasil analisis $\mathrm{R} / \mathrm{C}$ ratio menunjukkan tidak terdapatnya peternak yang mengalami kerugian dengan nilai tertinggi rasionya 1,158 pada peternak skala IV. Hasil analisis Break Event Point (BEP) melebihi titik impas baik BEP produksi dan harga pada setiap skala. Peternak mitra memperoleh banyak manfaat seperti bantuan modal, penyuluhan serta pemasaran hasil.
\end{abstract}

Kata Kunci : Ayam Broiler, Pola Kemitraan, Biaya, Pendapatan.

\section{PENDAHULUAN}

Ayam broiler adalah salah satu unggas yang digemari dikalangan masyarakat hal ini karena lebih mudah pemeliharaannya dan sudah banyak dipelihara para peternak sejak dahulu sampai sekarang, terutama di daerah pinggiran kota besar serta pedesaan. Hal tersebut disebabkan beberapa hal, antara lain produksinya berupa daging dan telur dapat dinikmati seluruh lapisan masyarakat. Adapun populasi ayam broiler di provinsi jawa barat terus meningkat mulai dari tahun 2015 sebanyak 631.154.917 ekor, pada tahun 2016 sebanyak 649.829.868 ekor, pada tahun 2017 sebanyak 656.058.761 ekor dan pada tahun 2018 sebanyak 660.766.857 ekor (Ditjen PKH, 2018).

Dari data tersebut dapat disimpulkan bahwa ayam broiler 
memiliki peranan baik dan layak untuk diusahakan agar tercapainya masyarakat yang lebih sejahtera. Menjalankan usaha ternak ayam broiler lebih cepat mendatangkan hasil dari pada beternak ungags lainnya. Hal tersebut disebabkan pemeliharaan ayam broiler relatif cepat yaitu selama 5-8 minggu dengan bobot ayam berkisar antara 1,5-2,8 $\mathrm{Kg}$ /ekor dan dapat segera untuk dipanen. Dengan waktu pemeliharaan yang singkat maka perputaran modal dapat berjalan dengan lancar (Muslimin, 2002). Pola kemitraan adalah kerjasama antara peternak dengan pengusaha atau perusahaan yang memiliki tujuan tertentu yang serupa. Dalam menjalin kemitraan pihak pengusaha atau perusahaan memiliki posisi sejajar dengan pihak peternak demi tercapainya tujuan seperti perhitungan biaya produksi diatur oleh perusahaan dan pihak peternak dapat bernegosiasi sehingga tercapainya kesepakatan diantara kedua belah pihak yang menjalin kemitraan.

Pada dasarnya pola kemitraan adalah sebuah kerjasama bisnis untuk tujuan tertentu dan antara pihak yang bermitra harus mempunyai kepentingan dan posisi yang sejajar (Salam, 2006).

Masalah yang ditemukan di lapang adalah terkadang kerjasama kemitraan yang dijalankan tidak saling menguntungkan, hal tersebut karena pihak perusahaan memiliki power yang lebih bila dibandingkan dengan pihak peternak baik dalam hal permodalan, teknologi, pasar, dan manajemen. Dampaknya terhadap peternak seakan merupakan pekerja oleh perusahaan inti.
Permasalahan lainnya dari pihak peternak mitra adalah tidak dapat negosiasi terkait harga kontrak yang ditetapkan perusahaan, dalam penyediaan DOC sering terlambat dan kualitas DOC yang buruk, tetapi peternak tidak dapat bertindak banyak (Angriani, 2011).

Penelitian ini bertujuan untuk mengetahui karakteristik, pola kemitraan dan kelayakan usaha peternakan ayam broiler pola kemitraan di Kecamatan Nanggung.

\section{BAHAN DAN METODE}

\section{Tempat dan Waktu Penelitian}

Lokasi penelitian akan dilakukan di Kecamatan Nanggung Kabupaten Bogor, Jawa Barat. Waktu pelaksanaan penelitian ini pada bulan FebruariMaret 2019.

\section{Metode Penelitian}

Metode penelitian yang akan digunakan adalah metode kualitatif deskriptif dan kuatitatif, kualitatif yaitu menggambarkan karakteristik objek penelitian secara deskripsi. Menurut krisyanto (2008) jenis riset deskriptif bertujuan untuk membuat deskripsi secara sistematis, faktual, dan akurat tentang fakta-fakta dan sifat-sifat populasi atau objek-objek tertentu, sedangkan metode kuantitatif dilaku-kan untuk menganalisa kelayakan suatu usaha dari aspek finansial.

\section{Pengambilan Sampel}

Metode pengambilan sampel adalah purposive sampling yang diartikan pengambilan dari sampel berdasarkan kesengajaan, serta mendapatkan responden dengan metode snowball maka pemilihan sekelompok subjek 
menggunakan metode Sensus didasarkan atas ciri atau sifat tertentu yang dipandang mempunyai sangkut paut yang erat dengan ciri atau sifat populasi yang sudah diketahui sebelumnya. Peternak ayam yang dipilih sebagai sampel seluruh peternak ayam yang bermitra di

Kecamatan Nanggung, Kabupaten Bogor. Setiap peternak responden dibagi kedalam 3 skala usaha. Skala usaha dibagi berdasarkan skala kepemilikan pada periode pemeliharaan yang dikelompokkan berdasarkan skala usaha. Pada usaha ternak dengan skala I kepemilikan Antara 4.000 - 19.000 ekor sebanyak 7 peternak dengan rata-rata skala usaha peternak 13.571 ekor, skala II terdiri dari peternak dengan skala kepemilikan Antara 20.000 - 29.000 ekor (6 peternak)dengan rataan skala usaha sebesar 22.000 ekor, dan skala III terdiri dari peternak dengan skala kepemilikan Antara 30.000 - 60.000 sebanyak 5 peternak hasil rata-rata sebesar 39.200.

\section{Teknik Pengumpulan Data}

Data primer adalah data yang dikumpulkan untuk keperluan pengkajian khusus. Proses pengumpulan, pencatatan dan jenis spesifikasinya ditentukan oleh pemakai. Metode pengumpulannya dapat dilakukan dengan cara melalui pengamatan langsung dan wawancara dengan responden melalui kuesioner. Data sekunder adalah data yang pengumpulan, pen-catatan dan penentuan spesifikasinya dilakukan bukan oleh pemakai tetapi oleh pihak lain. Data jenis ini merupakan sumber informasi yang penting bagi pengkajian aspek pasar. Sumber data sekunder yang terbesar berasal dari badan pemerintah seperti Badan Pusat Statistik serta sensus, penerbitan swasta dan asosiasi badan usaha (Subagyo, 2006).

\section{Analisis Data}

Data yang diolah dan dianalisis dalam penelitian ini adalah data kualitatif dan kuantitatif. Berdasarkan tujuan penelitian maka metode analisis data deskriptif pada tujuan menganalisis karakteristik peternak serta menganalisis pola kemitraan dan mandiri peternak dengan jenis data kualitatif. Data kualitatif mengenai gambaran umum pelaksanaan kemitraan dan profil para pelaku kemitraan akan dianalisis secara deskriptif. Data kuantitatif menggunakan analisis pendapatan, analisis $\mathrm{R} / \mathrm{C}$ ratio.

Analisis Pendapatan Usaha Ternak

Analisis ini digunakan untuk mengetahui besarnya penerimaan yang di dapat dalam usaha. Penerimaan kotor usaha ternak adalah jumlah produksi yang dihasilkan dalam suatu kegiatan usaha ternak dikalikan dengan harga jual yang berlaku dipasaran, adapun penerimaan usaha ternak adalah merupakan hasil perkalian antara produksi yang diperoleh dengan harga jual.

$$
\mathrm{TR}=\mathrm{Q} \times \mathrm{P}
$$

Dimana:

$\mathrm{TR}=$ Total Revenue (Rp/Thn)

$\mathrm{Q}=$ Jumlah Produksi per periode

$\mathrm{P}$ = Harga (Rupiah)

Dimana :

$$
\text { Biaya penyusutan }=\frac{\mathrm{Nb}-\mathrm{Ns}}{\mathrm{n}}
$$

$\mathrm{Nb}=$ Nilai Pembelian, dalam $\mathrm{Rp}$

$\mathrm{Ns}=$ Tafsiran nilai sisa, dalam $\mathrm{Rp}$

$\mathrm{n}$ = Jangka usia ekonomi, dalam tahun 


$$
\mathrm{P}=\mathrm{TR}-(\mathrm{Bt}+\mathrm{Btt}) \mathrm{VC}
$$

Dimana :

$\mathrm{P}=$ Pendapatan total usahatani

$\mathrm{TR}=$ Total penerimaan

$\mathrm{Bt}=$ Biaya tunai

$\mathrm{Btt}=$ Biaya tidak tunai

$\mathrm{VC}=$ Variabel Cost

$$
\mathrm{Pt}=\mathrm{TR}-\mathrm{Bt}(\mathrm{VC}+\mathrm{FC})
$$

Dimana :

$\mathrm{Pt}=$ Pendapatan tunai usahatani

$\mathrm{TR}=$ Total penerimaan

$\mathrm{Bt}=$ Biaya tunai

$\mathrm{VC}=$ Variabel cost

$\mathrm{FC}=$ Fix cost

Analisis Kelayakan Usaha Aspek Finansial

$$
\mathrm{R} / \mathrm{C}=\frac{\text { Total Hasil Produksi (Rp/ekor) }}{\text { Total Biaya Produksi (Rp/ekor) }}
$$

Kriteria yang sering dipakai dalam menilai suatu usaha ditentukan : $\mathrm{R} / \mathrm{C}>1=$ Usaha tersebut boleh dilaksanakan

$\mathrm{R} / \mathrm{C}<1=$ Usaha tersebut ditolak karena tidak menguntungkan $\mathrm{R} / \mathrm{C}=1=$ Usaha tersebut hanya mengembalikan modal produksi

Apabila $\mathrm{R} / \mathrm{C}$ ratio $>1$ maka suatu usaha dikatakan efisien. Hal ini menunjukkan semakin tinggi nilai $\mathrm{R} / \mathrm{C}$ maka tingkat pengembalian yang diterima petani untuk setiap rupiahnya semakin tinggi. Jika $\mathrm{R} / \mathrm{C}<1$ maka usaha ini tidak efisien artinya petani mengalami kerugian, karena penerimaan yang diterima oleh petani lebih kecil daripada biaya yang dikeluarkan oleh petani. Apabila $\mathrm{R} / \mathrm{C}=1$ maka petani tidak untung dan tidak rugi, artinya jumlah penerimaan petani sama dengan biaya yang dikeluarkan petani tersebut (Soekartawi, 2006).

Dalam menghitung Break Event Point atau titik impas digunakan rumus sebagai berikut:

BEP unit $=\underline{\text { Total Biaya Produksi }(\mathrm{Rp})}$ Harga Ayam (Rp/Kg)

BEP harga $=$ Total Biaya Produksi (Rp) Total Produksi (Kg)

Jika nilai BEP unit = jumlah produksi ayam $(\mathrm{Kg})$, maka usaha tersebut berada pada titik impas tidak mengalami keuntungan dan kerugian, sehingga untuk memeperoleh keuntungan peternak harus memproduksi dan menjual dengan jumlah lebih tinggi dari nilai BEP.

Jika nilai $\mathrm{BEP}$ harga = harga ayam broiler $(\mathrm{Rp} / \mathrm{Kg})$, maka usaha tersebut berada pada titik impas tidak mengalami kentungan dan kerugian, sehingga untuk memeperoleh keuntungan peternak harus memproduksi dan menjual dengan harga lebih tinggi dari nilai BEP.

\section{HASIL DAN PEMBAHASAN}

\section{Karakteristik Peternak}

Tabel 1 Usia Peternak Responden

\begin{tabular}{lcc}
\hline $\begin{array}{l}\text { Kelompok } \\
\text { Umur } \\
\text { (Tahun) }\end{array}$ & \multicolumn{2}{c}{ Peternak Mitra } \\
\cline { 2 - 3 } & $\begin{array}{c}\text { Jumlah } \\
\text { (orang) }\end{array}$ & $\begin{array}{c}\text { Persentase } \\
(\%)\end{array}$ \\
\hline $36-45$ & 11 & 61,3 \\
$46-55$ & 4 & 22,3 \\
$>56$ & 2 & 11,2 \\
\hline Jumlah & 17 & 100 \\
\hline \multicolumn{3}{c}{ Umur merupakan salah satu } \\
parameter untuk mengetahui karak- \\
teristik peternak responden. Respon \\
yang di pilih peneliti merupakan
\end{tabular}


responden yang berasal dari dalam kelompok ternak mitra. Peternak responden mitra sebagian besar berumur 36 hingga 45 tahun yaitu sebesar $49,9 \%$. Jumlah responden yang diketahui usianya berjumlah 17 responden karna 1 responden peternak mitra merupakan perusahaan PT. Tunas Mekar Gemilang yang melaksanakan usaha budidaya.

Tabel 2 Pengalaman Beternak Peternak

\begin{tabular}{lcc}
\hline Pengalaman & \multicolumn{2}{c}{ Peternak Mitra } \\
\cline { 2 - 3 } $\begin{array}{l}\text { Beternak } \\
\text { (Tahun) }\end{array}$ & $\begin{array}{c}\text { Jumlah } \\
\text { (orang) }\end{array}$ & $\begin{array}{c}\text { Persentase } \\
(\%)\end{array}$ \\
\hline$<5$ & 13 & 72,2 \\
$6-10$ & 5 & 27,8 \\
\hline Jumlah & 18 & 100 \\
\hline
\end{tabular}

Pengalaman beternak merupakan salah satu point penting dalam usaha peternakan. Pengalaman dapat dijadikan acuan untuk melihat bagaimana kemampuan peternak mengelola usaha ternaknya. Peternak responden mitra sebagian besar memiliki pengalaman beternak di bawah 5 tahun yaitu sebesar $72,2 \%$.

Tabel 3 Tingkat PendidikanResponden

\begin{tabular}{lcc}
\hline \multirow{2}{*}{$\begin{array}{c}\text { Tingkat } \\
\text { Pendidikan }\end{array}$} & \multicolumn{2}{c}{ Peternak Mitra } \\
\cline { 2 - 3 } & $\begin{array}{c}\text { Jumlah } \\
\text { (orang) }\end{array}$ & $\begin{array}{c}\text { Persentase } \\
(\%)\end{array}$ \\
\hline S2 & 1 & 5,6 \\
S1 & 6 & 33,3 \\
SMA & 19 & 55,6 \\
SMP & 1 & 5,6 \\
\hline Jumlah & 17 & 100 \\
\hline
\end{tabular}

Pengelompokkan responden berdasarkan tingkat pendidikan di kelompok mitra dapat digolongkan dari berbagai tingkatan. Kelompok mitra didominasi lulusan Sekolah menengah Atas (SMA) sebesar 55,6\%. Jumlah responden yang diketahui Tingkat pendidikannya berjumlah 17 responden karena 1 responden tidak dapat di-identifikasi karena peternak mitra merupakan perusahaan PT. Tunas Mekar Gemilang yang melaksanakan usaha budidaya di Kecamatan Nanggung.

Tabel 4 Sumber Modal Peternak

\begin{tabular}{lcc}
\hline Sumber & \multicolumn{2}{c}{ Peternak Mitra } \\
\cline { 2 - 3 } & $\begin{array}{c}\text { Jumlah } \\
\text { (orang) }\end{array}$ & $\begin{array}{c}\text { Persentase } \\
(\%)\end{array}$ \\
\hline Pribadi/ & 15 & 83,3 \\
Keluarga & & 11,1 \\
Bank & 2 & 5,6 \\
Perusahaan & 1 & 100 \\
\hline Jumlah & 18 & \\
\hline
\end{tabular}

Modal diperlukan agar usaha ternak yang di rencanakan dapat berjalan dengan demikian modal merupakan suatu elemen wajib dalam menjalankan usaha ternak. Sumber modal dapat berasal dari berbagai pihak seperti pribadi, bank, perusahaan inti dan pemerintah setempat. Pada kelompok mitra hasilnya yaitu sumber modal didominasi pribadi/keluarga sebesar $83,3 \%$. Data tersaji pada table di bawah ini.

\section{Analisis Pola Kemitraan}

Kemitraan adalah suatu bentuk kerjasama antara dua pihak atau lebih. Pihak yang terlibat dapat terdiri atas pengusaha, buruh, pemasok, pelanggan, petani atau pemerintah. Hubungan kerjasama ini dapat bersifat formal yaitu dengan sistem kontrak dan berada pada kalangan intern ataupun tidak

formal. 
Tabel 5 Pemasaran Ayam Broiler

\begin{tabular}{lcc}
\hline \multirow{2}{*}{ Pemasaran } & \multicolumn{2}{c}{ Peternak Mitra } \\
\cline { 2 - 3 } & Jumlah (orang) & Persentase(\%) \\
\hline Perusahaan Inti & 13 & 72,2 \\
Konsumen sekitar & 2 & 11,1 \\
Pasar & 1 & 5,6 \\
Pedagang pengepul & 2 & 11,1 \\
\hline Jumlah & 18 & 100 \\
\hline
\end{tabular}

Pemasaran ayam broiler oleh peternak mitra baik hanya melalui perusahaan inti atau pemasaran lainnya. Pada kelompok ternak mitra pemasaran didominasi pemasaran hanya melalui perusahaan inti sebesar $72,2 \%$.

Tabel 6 Karakteristik Pola Kemitraan pada Usaha Ayam Broiler

\begin{tabular}{lcc}
\hline Keterangan & \multicolumn{2}{c}{ Peternak Mitra } \\
\cline { 2 - 3 } & Jumlah (Orang) & Persentase (\%) \\
\hline Keuntungan & 13 & 72,2 \\
Pemasaran Terjamin & 5 & 27,8 \\
Sapronak Mudah & 11 & \\
\hline Kelemahan & 7 & 61,1 \\
Terdapat Pemotongan & & 38,9 \\
Kualitas Sapronak Jelek & 14 & 77,8 \\
Sumber Ilmu Pengetahuan & 1 & 5,6 \\
Pemantauan Perusahaan Inti & 3 & 16,7 \\
Kunjungan Pemerintahan & & \\
Belajar Sendiri & 2 & 11,1 \\
Perusahaan Inti & 1 & 5,6 \\
PT Japfa & 1 & 5,6 \\
PT. Peternakan Ayam Nusantara & 2 & 11,1 \\
PT. Dramaga Unggas Farm & 10 & 55,6 \\
PT. sierad Produce & 2 & 11,1 \\
PT. Tunas Mitra Gemilang & & \\
PT. Charoen Pokphand Indonesia & 16 & 88,9 \\
\hline Pola Kemitraan & 2 & 11,1 \\
Inti Plasma & & \\
Kerjasama Operasional Agribisnis & &
\end{tabular}

Pengelompokkan responden berdasarkan alasan peternak ayam broiler untuk beternak dengan pola mitra. Pada peternak mitra sebesar $72,2 \%$ peternak menjawab keuntungan ialah pemasaran lebih terjamin. Pengelompokkan responden berdasarkan kelemahan peternak dalam menjalankan usaha ternaknya dengan pola bermitra. Dominasi 
kelemahan dalam usaha ternaknya yaitu terdapat potongan harga jika target yang diberikan perusahaan inti tidak tercapai, hasil ulasan tersebut sebesar 61,1\%. Sumber ilmu pengetahuan yang didapatkan peternak merupakan hal penting untuk melihat bagaimana peternak berusaha mencari ilmu pengetahuan untuk memajukan usahanya. Peternak responden mitra sebagian besar mendapat sumber pengetahuan dari pemantauan oleh perusahaan inti yaitu sebesar 77,8\%. Perusahaan PT. Tunas Mitra Gemilang (TMG) mendominasi sebagai perusahaan inti bagi Peternak ayam broiler dengan pola kemitraan di Kecamatan Nanggung. Dengan persentase sebesar 55,6 persen dan jumlah peternak sebanyak 10 peternak. Selanjutnya untuk PT. JAPFA, PT Sierad Produce dan PT. Charoen Phokpan masing-masing memiliki persentase sebesar 11,1 persen dengan peternak mitra sebanyak 2 orang. PT. Peternakan Ayam Nusantara (PAN) dan PT. Dramaga Unggas Farm memiliki peternak mitra terendah untuk Kecamatan Nanggung dengan persentase sebanyak 5,6 persen dengan jumlah peternak sebanyak 1 orang. Pengamatan penulis Peternak bermitra dengan PT. TMG Karena Di Kecamatan Nanggung terdapat kantor perusahaan inti di Kecamatan Nanggung, hal ini berpengaruh terhadap pemantauan perusahaan ke peternak mitra dapat dilakukan rutin dan berkala. Selain itu, tidak terdapatnya peternak yang merasa kerugian dalam menjalankan usaha bermitra dengan PT. TMG sehingga reputasi perusahaan inti dalam keadaan baik.

Dari perusahaan Inti yang melakukan kemitraan dengan peternak ayam broiler di Kecamatan Nanggung, terdapat beberapa sistem kemitraan yang diterapkan. Pola kemitraan yang dibangun perusahaan inti dengan peternak mitra adalah pola inti-plasma yaitu kerjasama kemitraan antara perusahaan inti dengan peternak plasma di jalankan berdasarkan perjanjian yang telah disepakati dan ditandatangani kedua belah pihak. Perusahaan inti memiliki kewajiban untuk menyediakan sarana produksi ternak, melakukan pembinaan, dan memasarkan hasil panen peternak plasma sedangkan kewajiban peternak plasma adalah menyediakan kandang, memelihara ayam broiler, melapor kepada inti jika terjadi kematian atau serangan penyakit, menggunakan sarana produksi ternak dari inti, dan menjual hasil panen kepada inti.

Dari hasil analisa penulis dapat disimpulkan hamper seluruh peternak responden menjalankan usaha ternaknya dengan pola kemitraan Inti plasma dengan persentase sebesar 88,9 persen dan jumlah peternak sebanyak 16 orang. Pola Kerjasama Operasional Agribisnis (KOA) sebanyak 2 orang dengan persentase sebesar 11,1 persen.

\section{Analisis pendapatan, $\mathrm{R} / \mathrm{C}$ dan BEP peternak ayam broiler}

Pendapatan tunai usahatani adalah selisih antara penerimaan tunai usahatani dan pengeluaran tunai usahatani dimana digunakan untuk mengukur kemampuan usahatani untuk menghasilkan uang tunai. Pendapatan bersih usahatani adalah selisi antara pendapatan kotor usahatani dan pengeluaran total usahatani dan digunakan untuk mengukur imbalan yang diperoleh keluarga petani dari penggunaan 
faktor-faktor produksi kerja, Struktur biaya usaha ternak ayam pengelolaan, dan modal milik sendiri broiler menurut skala usaha dapat atau modal pinjaman yang dilihat pada Tabel di bawah ini. diinvestasikan kedalam usahatani.

Tabel 7 Struktur Biaya Usaha Ternak Menurut Skala di Kecamatan Nanggung

\begin{tabular}{lrrrrrr}
\hline \multicolumn{1}{c}{ Komponen Biaya } & \multicolumn{2}{c}{ Skala I } & \multicolumn{2}{c}{ Skala II } & \multicolumn{2}{c}{ Skala III } \\
& Rp/ekor & $(\%)$ & Rp/ekor & $(\%)$ & Rp/ekor & $(\%)$ \\
\hline A. Biaya Tunai & & & & & & \\
$\quad$ Biaya Tetap & & & & & & \\
- Pemeliharaan kandang & 46 & 0,23 & 41 & 0,22 & 32 & 0,17 \\
\hline Sub Total & 46 & 0,23 & 41 & 0,22 & 32 & 0,17 \\
\hline Biaya Variabel & & & & & & \\
- DoC & 5.947 & 30,22 & 5.988 & 32,97 & 6.035 & 33,22 \\
- Pakan & 13.874 & 65,40 & 11.179 & 61,55 & 11.179 & 61,54 \\
- $\quad$ Obat \& Vaksin & 25 & 0,12 & 22 & 0,12 & 71 & 0,39 \\
- Sekam & 215 & 1,09 & 202 & 1,11 & 214 & 1,17 \\
- Listrik & 91 & 0,46 & 162 & 0,89 & 128 & 0,70 \\
- Tenaga Kerja & 420 & 2,13 & 498 & 2,74 & 428 & 2,35 \\
\hline Sub Total & 19.572 & 99,44 & 18.051 & 99,32 & 18.055 & 99,39 \\
\hline Total Biaya Tunai & 19.618 & 99,67 & 18.092 & 99,54 & 18.088 & 99,57 \\
\hline B. Biaya Tidak Tunai & & & & & & \\
Biaya Tetap & & & & & & \\
- Penyusutan Kandang & 35 & 0,18 & 39 & 0,21 & 50 & 0,27 \\
- Penyusutan Peralatan & 16 & 0,09 & 15 & 0,08 & 16 & 0,08 \\
- Pemanas \& ventilasi & 12 & 0,06 & 14 & 0,07 & 11 & 0,06 \\
\hline Total Biaya Tidak Tunai & 63 & 0,33 & 68 & 0,36 & 77 & 0,42 \\
\hline Total Biaya & 19.681 & 100 & 18.160 & 100 & 18.165 & 100 \\
\hline & & & & & &
\end{tabular}

Total biaya tunai yang dikeluarkan peternak dengan Skala III lebih kecil dibandingkan peternak skala I dan II. Hal ini diketahui dari total biaya tunai peternak skala III sebesar Rp. 18.088/ekor atau 99,97\% dan peternak skala II sebesar Rp. 18.092/ ekor atau 99,54\%, sedangkan pada peternak skala I biaya tunai sebesar Rp. 19.618/Kg atau 99,64\% dari total biaya yang dikeluarkan masing-masing peternak. Tingginya total biaya tunai masing-masing peternak dikarenakan terdapat komponen biata tunai terbesar yaitu biaya pakan. Hal ini diketahui dari proporsi biaya pakan yang dikeluarkan peternak skala I sebesar $65,40 \%$, skala II sebesar $61,55 \%$ dan skala III sebesar $61,54 \%$. Selain itu, biaya tunai terbesar kedua yang dikeluarkan peternak adalah biaya Day Old Chicken (DOC) 
dengan persentase masing-masing sebesar $30,22 \%$ pada skala I, 32,97\% pada skala II dan $33,22 \%$ pada skala III.

Biaya tidak tunai yang dikeluarkan peternak skala III lebih besar dibandingkan peternak skala I dan II. Hal ini ditunjukkan dengan persentase peternak skala III sebesar $0,42 \%$, peternak skala II sebesar $0,36 \%$ dan peternak skala I sebesar $0,33 \%$. Komponen biaya tidak tunai terbesar yang dikeluarkan masingmasing peternak adalah biaya penyusutan kandang. Biaya total yang di keluarkan peternak skala II lebih kecil daripada peternak skala I dan III hal ini ditunjukkan dari biaya total peternak skala III sebesar Rp. 18.165/ekor, peternak skala II sebesar
Rp. 18.160/ekor dan skala I sebesar Rp. 19.681/ekor. Penyebab biaya total skala II lebih kecil adalah skala usaha yang diterapkan termasuk sedang yang artinya biaya input tidak terlalu tinggi layaknya skala I dan biaya tidak tunai juga tidak tinggi.

Pendapatan usaha ternak ayam broiler adalah selisih antara penerimaan total dengan pengeluaran total selama proses produksi. R/C Rasio adalah analisis yang bertujuan untuk meng-ukur efisiensi inpu-output, dengan menghitung perbandingan antara penerimaan total dengan biaya produksi total. Perhitungan pendapatan dan nilai $\mathrm{R} / \mathrm{C}$ rasio peternak plasma pada skala I, II dan III dapat di lihat pada tabel di bawah ini.

Tabel 8 Analisis Keuntungan dan R/C Rasio

\begin{tabular}{lrrr}
\hline Keterangan & \multicolumn{1}{c}{ Skala I } & \multicolumn{1}{c}{ Skala II } & \multicolumn{1}{c}{ Skala III } \\
\cline { 2 - 4 } & \multicolumn{1}{c}{ Total $(\mathrm{Rp})$} & \multicolumn{1}{c}{ Total $(\mathrm{Rp})$} & \multicolumn{1}{c}{ Total $(\mathrm{Rp})$} \\
\hline Total Penerimaan & 295.071 .457 & 463.824 .950 & 839.008 .000 \\
Total Biaya & 267.071 .265 & 398.677 .525 & 708.472 .973 \\
Keuntungan & 27.933 .191 & 64.230 .758 & 130.535 .026 \\
R/C Rasio & 1,10 & 1,16 & 1,18
\end{tabular}

Untuk melihat perbandingan usaha ternak ayam broiler dengan skala usaha yang berbeda dapat diukur dari efisiensi usaha, misalnya $\mathrm{R} / \mathrm{C}$ rasio. Berdasarkan perhitungan $\mathrm{R} / \mathrm{C}$ rasio ketiga skala usaha peternakan ayam broiler diatas dapat diketahui bahwa ketiga skala tersebut memperoleh hasil >1 yang dapat diartikan ketiga skala usaha tersebut dapat dikatakan layak dan menguntungkan bagi peternak. Pada skala I nilai penerimaan peternak sebesar Rp. 295.071.457,-- serta dengan biaya yang dikeluarkan peternak sebesar Rp. 267.071.265,- dengan begitu keuntungan yang diterima peternak sebesar Rp. 27.933.191,- per periode dengan hasil $\mathrm{R} / \mathrm{C}$ sebesar 1,20 yang berarti setiap Rp. 1,- yang dikeluarkan peternak untuk memproduksi ayam broiler dapat menghasilkan Rp. 1,10,-. Pada skala II total penerimaan peternak sebesar Rp. 463.824.950,- dengan total biaya produksi sebanyak Rp. 398.677.525,dan total keuntungan yang diperoleh oleh peternak sebesar Rp. 64.230.758,- 
dengan begitu usaha pada skala ini juga dapat dikatakan layak dengan nilai R/C sebesar 1,16. Pada skala III hasil nilai $\mathrm{R} / \mathrm{C}$ tertinggi yaitu 1,18 dengan penerimaan peternak sebesar Rp. 839.008.000,- dan total biaya sebesar Rp. 708.472.973,- serta keuntungan yang diperoleh peternak pada skala ini sebesar Rp. 130.535.026,-. Dari analisa tersebut penulis dapat menyimpulkan bahwa skala usaha mempengaruhi agar tercapainya keuntungan yang maksimal, sehingga semakin tinggi biaya produksi yang dikeluarkan peternak maka semakin tinggi pula keuntungan yang diterima oleh peternak.

Break Event Point (BEP) merupakan suatu keadaan dimana kondisi penerimaan dalam suatu usaha ternak ayam broiler sama dengan total biaya yang dikeluarkan, sehinggan usaha tersebut tidak mengalami kerugian atau keuntungan. Perhitungan BEP ini berdasarkan pada dua analisis, yakni berdasarkan hasil unit $(\mathrm{Kg})$ dan berdasarkan harga (Rp). harga dan produksi ayam broiler yang diusahakan peternak lebih besar dibandingkan nilai BEP harga, sehingga peternak mendapatkan keuntungan dan layak untuk dijalankan. Maka agar seluruh peternak ayam broiler pola kemitraan di Kecamatan Nanggung agar terhindar dari kerugian harus menjual ayam dengan harga diatas BEP harga. Untuk BEP unit peternak harus memproduksi ayam lebih dari hasil nilai BEP unit agar meminimalisir peternak meng-alami kerugian.

BEP unit secara kieseluruhan produksi ayam broiler pola kemitraan di Kecamatan Nanggung sudah mencapai titik impas atau mendapatkan keuntungan. Jumlah produksi ayam broiler agar usaha ternak ayam broiler di Kecamatan Nanggung tidak mengalami kerugian untuk skala I minimal 11.770,02 Kg, skala II minimal $17.985,45 \mathrm{Kg}$ dan pada skala III minimal peroduksi sebesar $31.857,79 \mathrm{Kg}$. Hasil analisis BEP pada usaha ternak ayam broiler pola kemitraan di Kecamatan Nanggung dilihat pada tabel 9.

Tabel 9 Analisis Break Event Point (BEP) Pada Usaha Ternak Ayam broiler

\begin{tabular}{ccrrr}
\hline Keterangan & Satuan & \multicolumn{1}{c}{ Skala I } & \multicolumn{1}{c}{ Skala II } & \multicolumn{1}{c}{ Skala III } \\
\hline Total Biaya & Rp/Periode & 266.506 .980 & 398.677 .525 & 707.242 .974 \\
Produksi Ayam & Kilogram & 13.629 & 20900 & 37240 \\
BEP Unit & Kilogram & $11.770,02$ & $17.985,45$ & $31.857,79$ \\
Harga Jual & Rp/Kg & 22.642 & 22.166 & 22.200 \\
BEP Harga & Rp/Kg & $19.553,55$ & $19.075,48$ & $18.991,48$
\end{tabular}




\section{KESIMPULAN DAN IMPLIKASI KEBIJAKAN}

\section{Kesimpulan}

Hasil penelitian menunjukkan bahwa karakteristik responden peternak mitra sebagian besar memiliki umur Antara 36 hingga 45 tahun sebanyak 11 responden dengan persentase sebesar $61,3 \%$. Memiliki pengalaman beternak dibawah 5 tahun sebanyak 13 orang dengan pesentase $72,2 \%$, sumber ilmu beternak diperoleh dari pemantauan yang dilakukan perusahaan inti secara berkala sebanyak 14 responden dengan persentase $77,8 \%$. Sebagian besar responden memiliki tingkat pendidikan SMA sebanyak 10 responden dengan persentase sebesar 55,6\%.

Keuntungan yang dirasakan peternak pada pola kemitraan adalah pemasaran produk lebih terjamin dengan responden sebanyak 13 orang dengan persentase $72,2 \%$. Kelemahan yang dirasakan oleh peternak dengan pola kemitraan adalah terdapat pemotongan harga yang ditetapkan oleh perusahaan inti kepada peternak jika hasil produksi tidak sesuai yang diinginkan. Pemasaran yang dijalankan oleh peternak ayam broiler dengan pola kemitraan di Kecamatan Nanggung Kabupaten Bogor adalah hanya melalui perusahaan inti dengan responden sebanyak 13 orang dan persentase sebesar 72,2\%. Seluruh peternak ayam broiler di Kecamatan Nanggung kabupaten Bogor memasarkan produk dalam bentuk Ayam hidup.

Hasil analisis R/C peternak mitra di Kecamatan Nanggung Kabupaten Bogor setiap usaha ternak yang dijalankan di-nyatakan layak karna hasil analis setiap peternak memperoleh nilai $>1$. Untuk peternak dengan nilai $\mathrm{R} / \mathrm{C}$ tertinggi yaitu skala III dengan hasil sebesar 1,18 dengan keuntungan yang mencapai $\mathrm{Rp}$ 130.535.026,-. Untuk analisis R/C terkecil pada peternakan skala I dengan hasil analisis sebesar 1,10 namun usaha yang dijalankan dikatakan layak karna dalam periode produksi masih mendapatkan keuntungan sebesar Rp. 27.933.191,-.

\section{Implikasi Kebijakan}

$\begin{array}{rcc}\text { Perusahaan } & \text { inti } & \text { perlu } \\ \text { memprioritaskan } & \text { pelayanan } & \text { yang }\end{array}$ dirasakan masih kurang oleh peternak plasma, yaitu terkait kualitas DOC, pakan, ketepatan pengiriman sapronak dan kecepatan pembayaran hasil panen. Pihak perusahaan inti dapat mencari dan menyeleksi dari beberapa produsen sapronak untuk mencari kualitas sapronak yang terbaik. Pengiriman sapronak harus sesuai yang di janjikan agar peternak tidak kecewa dan terhambatnya proses produksi. Pembayaran hasil panen peternak harus menjadi prioritas utama agar peternak tidak kecewa dan dapat mnggunakan dana untuk kebutuhan produksi yang akan datang.

Pihak perusahaan juga dapat memberikan penghargaan kepada peternak yang mampu mencapai target produksi yang ditetapkan perusahaan, sehingga peternak lain dapat mengetahui bahwa dengan standar yang ditetapkan saat ini sebenarnya dapat dicapai peternak. Dengan adanya penghargaan bagi peternak, maka akan memotivasi peternak lain untuk berusaha agar lebih baik. 
Daftar Pustaka

Angriani, E.D. 2011. Perbandingan Pendapatan Antara Peternak Mitra dan Peternak Mandiri Ayam Broiler di Kabupaten Bungo. [Skripsi]. Fakultas Peternakan Universitas Andalas, Padang.

Badan Pusat Statistik. 2017. Kabupaten Bogor Dalam Angka 2017. http://bogorkab.bps.go.id [18 Desember 2018].

Ditjen PKH. 2018. Statistik Peternakan dan Kesehatan Hewan 2018. Direktorat Jendral
Peternakan dan Kesehatan Hewan. Kementrian RI.

Krisyanto, R. 2008. Teknis Praktik Riset Komunikasi. CV Kencana Prenada. Jakarta.

Muslimin. 2002. Budidaya Bina Ayam. Kanisius. Yogyakarta.

Salam, T. 2006. Analisis Finansial Usaha Peternakan Ayam Broiler Pola Kemitraan, Jurnal Agrisistem, Juni 2006 Vol 2 No. 1.

Subagyo, J. P., 2006. Metode penelitian dalam teknik dan praktek. PT. Rineka Cipta. Jakarta. 